The American Journal of Management and Economics Innovations

(ISSN - 2693-0811)

VOLUME 04 ISSUE 01 Pages: 5-13

SJIF IMPACT FACTOR (2020: 5. 307) (2021: 5. 562)

OCLC - 1176275019 METADATA IF -7.236

Crossref doi 81 Google (2)

Research Article

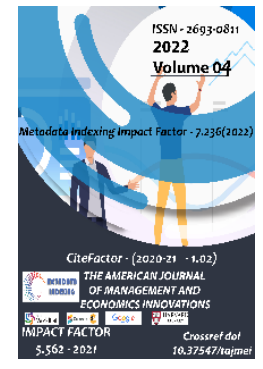

Journal Website: https://theamericanjou rnals.com/index.php/ta jmei

Copyright: Original content from this work may be used under the terms of the creative commons attributes 4.0 licence.

\section{ISSUES OF EVALUATION OF COMPETITION OF COMMERCIAL BANKS IN THE INTERBANK MARKET}

\author{
Submission Date: January 09, 2022, Accepted Date: January 20, 2022, \\ Published Date: January 30, 2022 | \\ Crossref doi: https://doi.org/10.37547/tajmei/Volume04Issue01-02 \\ Kulmetov Mansurbek Ruzmatovich \\ PhD, Department of Economics, Tashkent Financial Institute, Uzbekistan
}

\title{
ABSTRACT
}

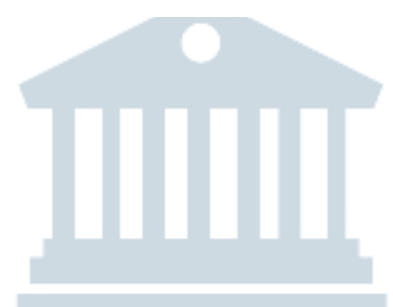

This article provides an in-depth analysis of methods for assessing the level of competition in the foreign banking market. On the basis of the Lerner index, the level of competition in the credit (deposit) market of commercial banks of the republic is assessed on the basis of bank indicators.

\section{KEYWORDS}

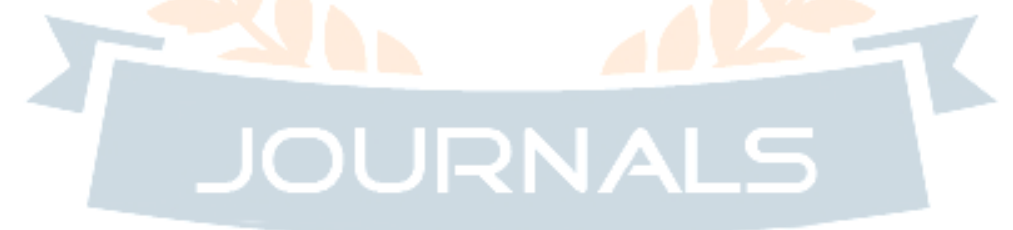

Capital adequacy, risky bank assets, competition, competition in the banking market, level of competition, Lerner index, Holt-Tideman model.

\section{INTRODUCTION}

At present, all operations in commercial banks directly or indirectly depend on its quality, and the adequacy of bank capital is a key factor in assessing the solvency and risk-free nature of any commercial bank. The bank's capital is the core of the bank's resources and determines the bank's financial stability reserve. Increases asset placement opportunities to ensure customer confidence in attracting high levels of capital resources and increase revenue. Commercial banks have sufficient banking capital, which allows them to 
The American Journal of Management and Economics Innovations (ISSN - 2693-0811)

VOLUME 04 ISSUE 01 Pages: 5-13

SJIF IMPACT FACTOR (2020: 5. 307) (2021: 5. 562)

OCLC - 1176275019 METADATA IF - 7.236

ensure liquidity and be competitive throughout their operations. The experience of developed countries shows that competition arises on the basis of economic development. Therefore, the formation of a competitive environment is a vital necessity for any country that has moved to market relations, because it is impossible to form market relations without developing competitive relations in the economy without allowing healthy competition. Nowadays, what factors to consider in determining the level of competition in financial markets is considered to be one of the main problems.

In the global banking system, the importance of managing banking risks, assessing the solvency of creditors, ensuring the financial stability of banks, organizing financial management in the fight against the crisis, ensuring competitiveness in the competitive market, attracting foreign investors and increasing customer confidence in the bank.

In Uzbekistan, special attention is paid to the process of improving competition among commercial banks in identifying and solving problems in the banking system. In particular, the Action Strategy for the further development of the Republic of Uzbekistan focuses on the reform of the banking system: important tasks such as

Further deepening of reforms in the banking system and increasing its effectiveness is one of the priorities of the policy pursued by the Government of the Republic. The President of the Republic of Uzbekistan Shavkat Mirziyoyev paid special attention to these issues, noting that "the main task of commercial banks today is to radically change their methods of work, to gain the trust of our citizens and entrepreneurs and become their real helper."
In order to accelerate the work in this direction, the President of the Republic of Uzbekistan PF-4947 of February 7, 2017 "On the Strategy for further development of the Republic of Uzbekistan", PF-5177 of September 2, 2017 "On priority measures to liberalize foreign exchange policy" Resolutions No. PP3270 of September 12, 2017 "On measures to further develop and enhance the stability of the banking system of the Republic" and other normative legal acts serve as guidelines.

\section{LITERATURE REVIEW.}

The basics of capital valuation of commercial banks, its development and management are covered and substantiated in the works of many foreign scholars.

In particular, the work of such scientists as V.M. Usoskin, R.G.Olkhova, Chris Barltrop is important in this regard.

Professor V.M.Usoskin considers bank capital as an important and integral part of the bank's financial resources. It can be seen that as a result of the fact that capital is considered an important and integral part of the bank's resources, its main (protective, operational and regulatory) functions have been neglected. Economist R.G Olkhova, in revealing the economic nature of bank capital, said that "the age of protection understood. Involvement in the price method is understood to change the interest rate depending on the market situation. If the bank changes the interest rate in the competitive market at time $t$, the competitors of the bank also reduce the interest rate in the interval $(t+1)$, and the bank also lowers the bank interest rate in the interval $(t+2)$. In the economic literature, this efficiency was realized in 1883 under the name of Joseph Bertrand (Bertrand's model focused on price competition in the oligopolistic market, Bertrand, 1883). In the face of fierce competition, the 
The American Journal of Management and Economics Innovations (ISSN - 2693-0811)

VOLUME 04 ISSUE 01 Pages: 5-13

SJIF IMPACT FACTOR (2020: 5. 307) (2021: 5. 562)

OCLC - 1176275019 METADATA IF - 7.236

Crossref

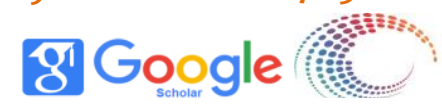
metaparn 5

Publisher: The USA Journals

bank offers attractive banking products in the market for its potential customers. In particular, a high level of customer service, a special approach based on the nature of borrowers for business, providing borrowers with an independent loan repayment period, reducing or eliminating loan fees, the use of co-branding technology for plastic cards (Mamonov et al.2011). Inexperienced methods allow you to create convenience for bank customers. At the same time, the customer will have to choose the right upper and lower limit when setting the interest rate for customer service. In competition, the banking system and the market will be closely intertwined. In this case, the first defines the classifications in the general field, which defines the basic features of microeconomics, the second defines the main features of microeconomics.

In assessing competition between banks, an assessment based on the "Peaceful Life" model developed by Hicksom (Hicks, 1935) was proposed.This is based on the fact that the decline in the efficiency of banks leads to a monopolistic position in the market (Berger, Hannan, 1998; Delis, Tsionas, 2009). These studies demonstrate methods for evaluating banks through performance indicators. The loss of "peaceful life" of banks through a decrease in the efficiency of banks is promoted by a second case, the assessment of the risks to banks (Berger, DeYoung, 1997; Fiordelisi et al., 2011). Recent research suggests that banks assess their level of competition by changing interest rates in the credit market. Therefore, in various literatures, evaluation by bank indicators has been accepted as a general theory. But the model proposed by Lerner in 1934 served to change these views. In evaluating monopolistic competition, Lerner concludes that by subtracting its costs from the price of a product, its ratio to its price allows the formation of accurate data. However, the proposed model did not allow the use of this model due to the lack of accurate data or difficulty in calculating the prices of banks' products and costs between 1990 and 2000. However, the ability of banks to calculate interest income and interest expenses has made it possible to use this model gradually. The report of the banks provided accurate information on the provision of information on active and passive operations on loans (deposits), the cost of banking products and their costs. The possibility of calculating the income of a loan portfolio is considered in the study of the proposal to use it as a loan price (Maudos, Fernandez de Guevara, 2007) or in the study of asset income as the price of banking products (Turk Ariss, 2010; Berger et al., 2009, etc.). out In the research, the assessment of competition is based on different approaches, in which the concept of valuation through credit price, banking product price, deposit price and cost has caused certain difficulties. The above evaluation models allow evaluation through a specific direction of the banking segment. These models do not allow a complete assessment of the banking system. As a result, the "structure-situation-result" paradigm proposed by Mason for a complete assessment of the banking system was developed SCP, StructureConduct-Performance; Mason, 1939).In addition, the Gerfindal-Hirschman ( $\mathrm{HHI}$ ) index, based on the share of banks in the indicators, and Goldberg, Rai (1996), Berger, Hannan (1998), Fu, Heffernan (2009); CRj index, Mirzaei et al. (2013) can cite indices. In addition, a study by Shaffer, DiSalvo (1994) found that the position of banks in the competitive market in countries with very small economies was positive. In a study by Claessens, Laeven (2005), competition between EU-selected banks over other banks

After the 1970s and 1980s, a new empirical approach to determining the level of competition developed. This line is known in the literature (NEIO, New Empirical Industrial Organization literature) and has become famous for its unstructured valuation theory. One such 
The American Journal of Management and Economics Innovations (ISSN - 2693-0811)

VOLUME 04 ISSUE 01 Pages: 5-13

SJIF IMPACT FACTOR (2020: 5. 307) (2021: 5. 562)

OCLC - 1176275019 METADATA IF - 7.236

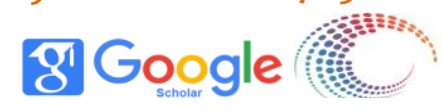

metapata
Inpexing

Publisher: The USA Journals

assessment method (Panzare, Rosse, 1987) suggests evaluating banks on individual indicators. In particular, the assessment of the level of competition in the credit market or the deposit market. Research includes: Bresnahan (1982) and Lau (1982) studies of the market situation using the elasticity indicator, Barros, Modesto (1999) research on the sensitivity of the bank to change its interest rate through changes in competitors' interest rates, optimization of operating costs The flexibility indicator Boone (2008) can be cited as an indicator of increasing its market share by doing. Panzara-Ross's H-statistical technique has become widespread (except for the Bun indicator) because it is easier to calculate using less data than other assessment methods. All created indicators can be divided into two blocks: microeconomic and general. The first is determined by the level of individual banks. The second covers a specific segment of the market or the banking sector as a whole. Only the Lerner index is an indicator of microeconomic evaluation, and the remaining indicators are taken as an assessment of competition in the industry as a whole. Subsequently, new evaluation indicators were created by summarizing the two blocks. One can cite the method of local optimization provided by Mantos Delis (local maximization technique). The advantage of this method is that any obtained macroindicators can be converted to the micro level by disaggregation. First, this method was applied to the banking sector of Delis, Tsionas (2009) EU 12 countries through the Bresnahan model. The second, using N-statistics by Brissmis, Delis (2011), applied 20 transition economies to the banking

$$
\text { Lerner }_{i t}=\frac{r_{L N S, i t}-A F R_{i t}-M C_{L N S, i t}}{r_{L N S, i t}}=\left\{\begin{array}{c}
\leq 0-\text { pure competition } \\
(0,1)-\text { monopolistic competition } \\
\geq 1-\text { monopoly }
\end{array}\right.
$$

sector of states. Third, Delis (2012) applied the banking sector of 84 developed and developing countries through this Bun indicator. Carbo et al. (2009) assessed the level of $14 \mathrm{EU}$ individual banks using $\mathrm{H}$-statistics. Drobyshevsk, Pashchenko (2006) from Russian researchers, Bresnakhan and Barush-Mudeshto models, Mamonov (2010a, b); Anisimov, Vernikov (2011) from N-statistics, Karminsky et al. (2012), Mamonov (2012) and Pestova, Mamonov (2013) used the Lerner index to assess the level of competition in Russian banking. et al., 2012.).

\section{RESEARCH METHODOLOGY}

The Lerner index at the micro level was used to assess the level of competition in the banking sector of the country. This method allows you to accurately assess the level of competition between banks in the credit (deposit) market of the country.

\section{ANALYSIS AND DISCUSSION OF RESULTS}

The use of the Lerner index in the credit market will change the level of competition due to the impact of changes in the market on the basis of bank credit prices, prices and prices of banking products. In some studies, Maudos, Fernandez de Guevara (2007), and Turkish Ariss (2010) used the funding-adjusted Lerner Index instead of the conventional Lerner Index to calculate the Lerner index. The researchers proposed a general calculation formula for the Lerner index as follows: 
The American Journal of Management and Economics Innovations (ISSN - 2693-0811)

VOLUME 04 ISSUE 01 Pages: 5-13

SJIF IMPACT FACTOR (2020: 5. 307) (2021: 5. 562)

OCLC - 1176275019 METADATA IF - 7.236

Crossref dol gु Google

on the loan placed by the bank during the year to the volume of problem loans in the last year.

Here, $r_{-}$(LNS, it) is the average weighted interest rat

by the ratio of interest income from the interest rate

$$
r_{L N S, i t}=(\text { Interest Income })_{i t}^{L N S} /\left(\frac{1}{5} * \sum_{j=1}^{5} L_{O A N S}, t-j+1\right)
$$

$A F R_{i t}$ is the average weighted interest rate set by the i-

th bank to attract liabilities at time $t$.

$$
A F R_{i t}=(\text { Expense })_{i t}^{F U N D S S} /\left(\frac{1}{5} * \sum_{j=1}^{5} F U N D S S_{i, t-j+1}\right)
$$

$M C_{L N S, i t}$ - i- Additional costs of the bank on t-term loans.

In addition, the calculation formula proposed by HallTaydman is as follows:

$$
H T=\frac{1}{2 * \sum_{i=1}^{N} R_{i} * Y_{i}-1}
$$

Here, $Y_{-}(i)$ is the market share of the $i$-th bank, $R_{-} i$ is the color of the $\mathrm{i}$-th bank by indicators, $\mathrm{N}$ is the number of banks in the market. The maximum value of $\mathrm{HT}$ is 1 , where the market position is a monopoly, and at a value of $1 / \mathrm{N}$ the market position provides pure competition. The analysis of assets in the banking market of the state of Belarus had the following appearance.

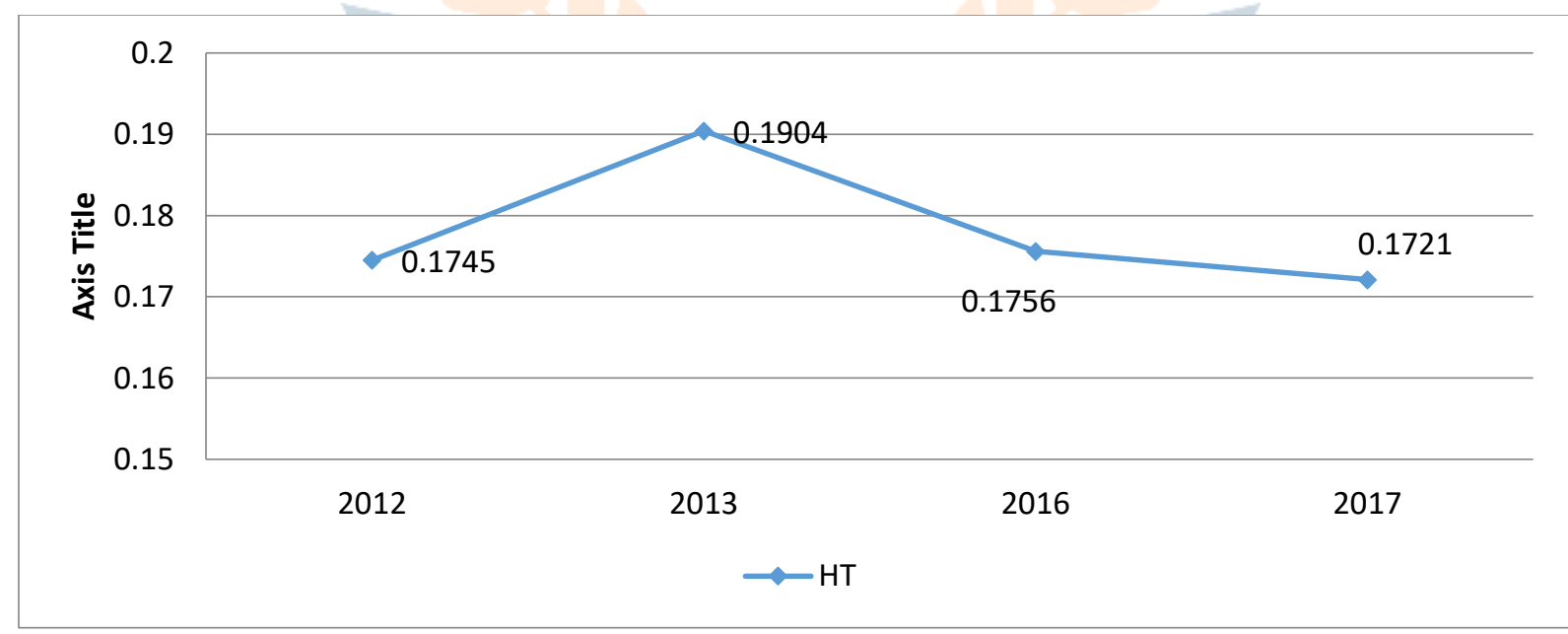

Figure 1. Dynamics of changes in the HT index on assets. 
The American Journal of Management and Economics Innovations (ISSN - 2693-0811)

VOLUME 04 ISSUE 01 Pages: 5-13

SJIF IMPACT FACTOR (2020: 5. 307) (2021: 5. 562)

OCLC - 1176275019 METADATA IF -7.236

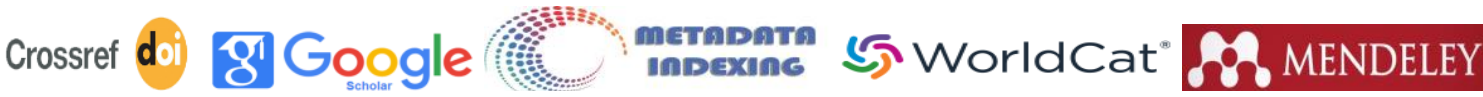

Here, $\mathrm{P}$ is the value of the resources placed; $M C$ - cost

follows:

$$
L=\frac{P-M C}{P}
$$

of resources involved.

$$
L_{2019}=\frac{211581-91009}{211581}=0,5698 ; \quad L_{2020}=\frac{276975-114747}{276975}=0,5857
$$

In our research, the indicators are $\mathrm{P}$ - percentage income; We assume $M C$ - interest expense. As of January 1, 2020, the interest income of all our banks amounted to 211581 billion soums, interest expenses amounted to 91009 bln. soums. As of January 1, 2021, respectively, 276975 bln. soums and 114747 bln. soums. Based on the given data, we calculate the Lerner index: When calculating the 9-year data of the banks of the Republic, we have the following results:

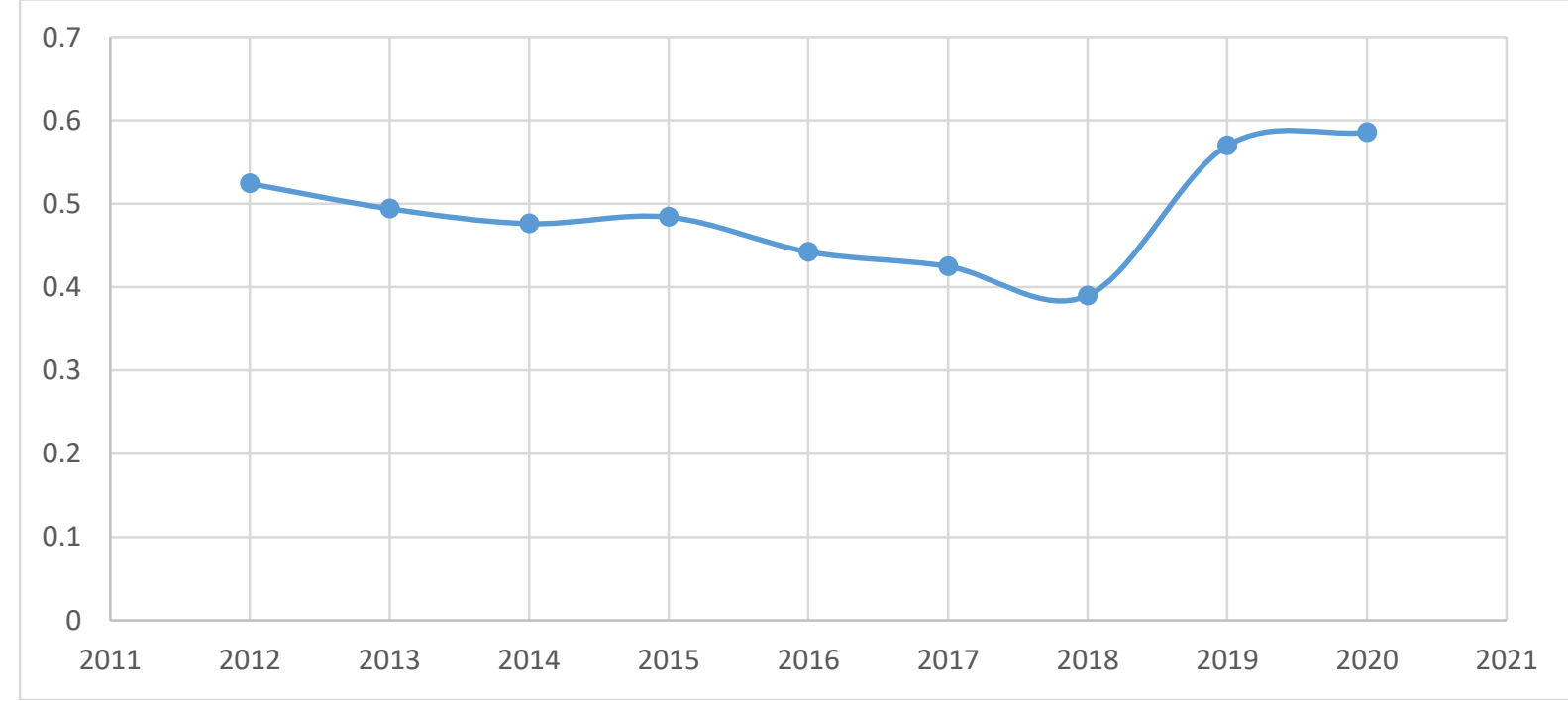

Figure 2. Dynamics of the Lerner index on interest income and expenses of commercial banks of the Republic.

Thus, if we pay attention to the criteria of the Lerner index, the indicators of interest income and expenses of the banks of the republic created a monopolistic competition ( $0.7<\mathrm{L}<1$ - monopoly, $0.3<\mathrm{L}<0.69$ monopolistic competition, $0<\mathrm{L}<0$, 29 - pure competition). We make the following changes to the formula for calculating the Lerner index on the share of banks in the credit and deposit market, which is the basis for interest income and expenses: 
The American Journal of Management and Economics Innovations

(ISSN - 2693-0811)

VOLUME 04 ISSUE 01 Pages: 5-13

SJIF IMPACT FACTOR (2020: 5. 307) (2021: 5. 562)

OCLC - 1176275019 METADATA IF -7.236

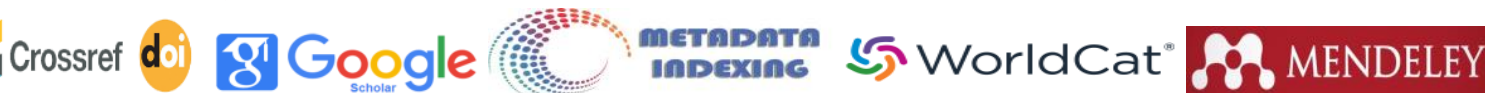

$$
L=\frac{\sum_{i=1}^{N} P_{i}-\sum_{i=1}^{N} M C_{i}}{\sum_{i=1}^{N} P_{i}}
$$

Here, $R_{-}(i)$ is the market share of the $i$-th bank in the loan market, MS _ (i) is the market share of the i-th bank in the deposit market, $\mathrm{N}$ - is the number of participating banks. We calculate the Lerner index for the share of state-owned banks in the credit and deposit market as of January 1, 2021.

Table 1.

On the main performance indicators of banks with a state share as of January 1, 2021 information billions of

sums

\begin{tabular}{|c|c|c|c|c|c|}
\hline \multirow[b]{2}{*}{ № } & \multirow[b]{2}{*}{ Bank name } & \multicolumn{2}{|c|}{ Credit } & \multicolumn{2}{|c|}{ Deposit } \\
\hline & & summa & $\begin{array}{l}\text { share, in } \\
\text { percent }\end{array}$ & summa & $\begin{array}{l}\text { share, in } \\
\text { percent }\end{array}$ \\
\hline & $\begin{array}{c}\text { Government share } \\
\text { existing banks }\end{array}$ & 244484 & $88 \%$ & 82461 & $72 \%$ \\
\hline 1 & NBU bank & 65598 & $23,7 \%$ & 17194 & $15,0 \%$ \\
\hline 2 & Uzpromstroybank & 39898 & $14,4 \%$ & 11437 & $10,0 \%$ \\
\hline 3 & Asaka bank & 34122 & $12,3 \%$ & 9705 & $8,5 \%$ \\
\hline 4 & Ipoteka bank & 24304 & $8,8 \%$ & 9499 & $8,3 \%$ \\
\hline 5 & Agrobank & 24997 & $9,0 \%$ & 9037 & $7,9 \%$ \\
\hline 6 & Xalkbanki & 18792 & $6,8 \%$ & 10174 & $8,9 \%$ \\
\hline 7 & Village construction bank & 13823 & $5,0 \%$ & 3777 & $3,3 \%$ \\
\hline 8 & Mikrokreditbank & 8540 & $3,1 \%$ & 2383 & $2,1 \%$ \\
\hline 9 & Turon bank & 6669 & $2,4 \%$ & 2116 & $1,8 \%$ \\
\hline 10 & Alokabank & 5706 & $2,1 \%$ & 4924 & $4,3 \%$ \\
\hline 11 & Asia Alliance Bank & 1852 & $0,7 \%$ & 2121 & $1,8 \%$ \\
\hline
\end{tabular}


The American Journal of Management and Economics Innovations (ISSN - 2693-0811)

VOLUME 04 ISSUE 01 Pages: 5-13

SJIF IMPACT FACTOR (2020: 5. 307) (2021: 5. 562)

OCLC - 1176275019 METADATA IF - 7.236

\section{Crossref doi g1 Google

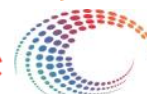

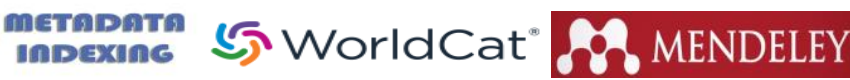

Publisher: The USA Journals

\begin{tabular}{|c|c|c|c|c|c|}
\hline 12 & Poytaxtbank & 110 & $0,04 \%$ & 74 & $0,1 \%$ \\
\hline 13 & Uzagroexportbank & 73 & $0,03 \%$ & 18 & $0,02 \%$ \\
\hline
\end{tabular}

$L_{2020}=\frac{88-72}{72}=0,2222222222$ Using the data in the table, we calculate the Lerner index:

The results show that the banks with a state share in this indicator are pure competition by the Lerner criterion.

5. Conclusions and suggestions. The following scientific conclusions were made on the basis of the research:

- The expediency of using the Lerner index in determining the competition in the credit (deposit) markets of commercial banks of the republic;

- When calculating the Lerner's index on the indicators of interest income and expenses of the republic, it was determined that the market situation is monopolistic competition;

- when calculating the Lerner index on the share of state-owned banks in the credit and deposit market, the market situation was considered to be pure competition;

- When using the Lerner index, banks are recommended to use the following criteria in assessing competition in our market: $0.7<1$ monopoly, $0.3<0.69$ - monopolistic competition, 0 $<0.29$ - pure competition.

There should be an appropriate infrastructure for the creation and development of an effective financial market, an important element of which is the activities of financial intermediaries. At present, credit institutions play a leading role in the monetary system of the Republic of Uzbekistan. Therefore, the efficiency of the banking system is largely determined by the stability and competitiveness of the entire economic system. In this regard, in the current situation, a qualitative analysis of the financial and economic condition of credit institutions is an urgent problem, one of the important components of which is the assessment and analysis of bank capital. The world now has a great deal of experience in assessing the value of commercial banks, their operations and capital. Existing approaches vary in focus, influencing factors, aspects of financial performance, as well as key data. However, all of them are more or less imperfect - they involve the subjectivity of the assessment, which in turn becomes the basis for debate. The limitations and shortcomings inherent in each classical approach to the assessment of bank capital do not allow it to solve the problem of a single universal indicator.

Therefore, the scientific article provides initial recommendations for improving the efficiency of the assessment of bank capital:

- Development of recommendations for the practical application of the assessment of the value of bank capital, which will help increase the reliability of information on the effectiveness of credit institutions;

\section{REFERENCES}

1. Admiraal P., Carree M. Competition and Market Dynamics on the Russian 
The American Journal of Management and Economics Innovations

(ISSN - 2693-0811)

VOLUME 04 ISSUE 01 Pages: 5-13

SJIF IMPACT FACTOR (2020: 5. 307) (2021: 5. 562)

OCLC - 1176275019 METADATA IF -7.236

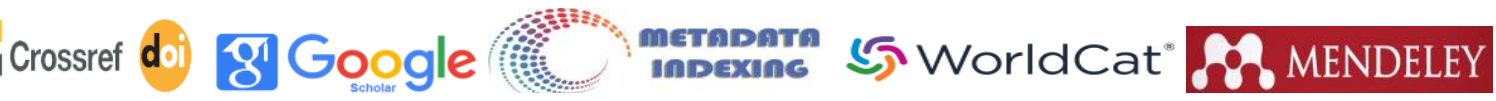

Publisher: The USA Journals

2. Deposits Market. ERIM Report Series in Research and Management, 25,

3. 2000.

4. Anzoategui D., Martínez Pería M.S., Melecky M. Bank competition in

5. Russia: an examination at different level of aggregation // Emerging Markets Review, 13. 2012. p. 42-57.

6. MR Kulmetov., Directions for improving competition between commercial banks., Dissertation August 21, 202072 p. 